\title{
Strategi Customer Relations Dan Kekayaan Media PT Mandiri Cipta Sejahtera Dalam Kondisi Pandemi COVID-19
}

\author{
Susilowati $^{1}$, Titi Widaningsih ${ }^{2}$, Toto Subandoro \\ ${ }^{1}$ Universitas Bina Sarana Informatika \\ e-mail: susilowati.ssi@bsi.ac.id \\ ${ }^{2}$ Universitas SAHID Jakarta \\ e-mail: titi_widaningsih@yahoo.com \\ ${ }^{3}$ Universitas SAHID Jakarta \\ e-mail: toto.soebandoro@gmail.com
}

\begin{tabular}{lll}
\hline Diterima : 2021-10-07 Direvisi :2021-11-13 Diterima: 2021-11-24 & D
\end{tabular}

\begin{abstract}
The Covid-19 pandemic hampers communication activities, namely the implementation of work from home (WFH) and causes difficulties in communicating the company with its customers, so efforts are needed in strategies to establish good relationships with customers. This study aims to examine and describe customer relationship strategies by using Zoom Cloud Meeting video conferencing. The concept used is the Concept of Customer Relations Strategy used is the Theory of Computer Mediated Communication (CMC) Qutlip and Wood and Smith and Media Richness Theory from Daft and Lengel. Research at PT Mandiri Cipta Sejahtera uses a qualitative approach with descriptive methods and uses the paradigm of postpositivism. Data analysis uses Huberman and Miles data analysis, namely Data Reduction in collecting field data such as interviews, Zoom Meeting videos, data from company websites and social media. The results of the study: (1) the strategy carried out by the company has fulfilled the stages of the customer relationship strategy, namely; Fact Finding, Planning and programming, action and communication, evaluation, and company activities have carried out customer relations, namely superior service to customers, excellent service (service off excellence) and good relations with customers (good relationship). (2) Using Zoom Cloud Meetings as a media resource, the implementation of Zoom Meetings is not entirely a medium that is capable of sending multiple signals, and is able to provide direct feedback, can perform various languages, symbols and share data, is also able to focus on delivering messages.
\end{abstract}

Keywords: Customer Relations Strategy, Video Conference, Computer Mediated Communications, Media Wealth

\section{PENDAHULUAN}

Kewajiban dalam sebuah perusahaan untuk menjalankan hubungan yang baik dengan pelanggannya dan ini merupakan sebuah kunci penting untuk perusahaan. Hubungan yang dilakukan dengan klien atau pelanggan dengan dilakukan dengan memberikan berbagai fasilitas untuk informasi secara utuh. Dengan memberitahukan atau informasi yang disiarkan oleh perusahaan memberikan suatu kemungkinan untuk memperoleh berbagai keluhan dari konsumennya, dan keluhan tersebut bida menjadi masalah yang wajib untuk diselesaikan dengan cara komunikasi yang baik.

Sebuah hubungan yang saling menguntungkan ini dapat diwujudkan oleh sebuah perusahaan kepada para konsumennya, sehingga perusahaan dapat dinyatakan sukses dapat diukur selain dari hasil keuntungan yang diraihnya tetapi dapat juga terlihat dari bagaimana perusahaan dapat menciptakan suatu hubungan yang baik dengan konsumennya secara jangka panjang. Hubungan dalam jangka yang panjang ini dapat dilakukan oleh perusahaan dengan 
menjaga hubungan yang baik dengan para pelanggannya dengan melakukan sebuah strategi untuk menjalin komunikasi guna pemenuhan kebutuhan serta kepuasan pelanggannya.

Keinginan dari pelanggan pastinya akan bermacammacam sehingga perusahaan wajib untuk melakukan pelayanan seperti apa yang diinginkan pelanggannya. Khususnya dalam perusahaan pada bidang jasa yang sbagian besarnya terletak pada hubungan dengan pelanggan.

Masalah yang dihadapi perusahaan yang berhubungan dengan pelanggan secara umum yaitu pelanggan memberikan pengajuan dengan bermacam-macam permintaan yang membutuhkan suatu pemikiran yang special pada perusahaan tersebut, itulah sebabnya perusahaan wajib untuk mencari upaya dengan cara memberikan saluran dari apa yang diinginkan pelanggan supaya bisa segera tertangani dan juga dapat cepat diproses dan diselesaikan.

Semua permasalahan ini tidak dapat terlaksana dengan baik dikarenakan adanya musibah dari pandemic COVID-19 sehingga mempunyai dampak terganggunya komunikasi tatap muka dengan pelanggan. Selama masa pandemi COVID-19 pihak pemerintah telah memberikan peraturan untuk seluruh sector guna memberhentikan berbagai kegiatan di kantor atau perusahaan, dan mengharuskan untuk melakukan pekerjaan kantor yang dilakukan di rumah tinggal masing-masing Work From Home (WFH), tujuannya untuk dalam antisipasi akan tersebar virus corona, sehingga perusahaan swasta ataupun instansi pemerintah yang berada di wilayah Jakarta telah diharuskan untuk mengikuti instruksi pemerintah tersebut.

Terdapat penelitian yang sudah dilakukan Kementrian Perencanaan Pembangunan Nasional (BAPPENAS) yang dilakukan pada awal tahuin 2020 yaitu dengan melakukan pencanangan percobaan dengan melakukan pekerjaan secara jarak jauh dengan sebutan Flexi Work. Meskipun belum didapatkan laporan dari hasil percobaan tersebut, tetapi pelaksanaan Flexi Work tersebut rtelah berjalan lancar disebabkan karena dilakukaan pada saat pandemic COVID-19 terjadi. Melakukan pekerjaan di rumah dijadikan sebagai kegiatan yang memang diwajibkan disaat kondisi pandemi COVID-19, dan terjadi suatu hal yang berbeda, dimana sebagian dari instansi dan perusahaan telah siap untuk melakukannya bahkan telah melaksanakan skema untuk melakukan pekerjaan dari rumah (WFH), dan memberlakukan untuk karyawan secara keseluruhan atau hanya sebagiannya saja. (Mungkasa, 2020)

Sepertihalnya yang dilakukan pada PT Mandiri Cipta Sejahtera atau sebuah instansi dan memiliki brand corporate Identity adalah MorenaRent, yaitu perusahaan yang menyewakan kendaraan bermotor (kendaraan roda dua dan roda empat), dan sebagian pelanggannya yaitu perusahaan-perusahaan yang memang sangat membutuhkan jasa sewa kendaraan tersebut.

Salah satu pernyataan dari Senior Manager Marketing dari PT Mandiri Cipta Sejahtera, yaitu Agung Setipo Nugroho, sebagai berikut:

"Di dalam perusahaan mempunyai sebuah problem yaitu dimana perusahaan yang menjadi pelanggan mempunyai kebijakan yang berbeda, sehingga seringnya terjadi komplain dan mengharuskan mencari jalan untuk melakukan komunikasi dan mendekati mereka sebagai strategi yang harus dipikirkan selama masa pandemic ini agar supaya mendapat solusi berupa kesepakatan bersama antara perusahaan dan pelanggan serta saling tiddak merugikan satu sama lainnya".

Permasalahan lainnya juga timbul sebagai dampak dari pandemic Covid-19, seperti yang diungkapkan oleh Nugroho (2020) bahwa;

"Dengan adanya pandemic membuat omzet perusahaan mengalami penurunan hingga $25 \%$ dikarenakan keterbatasa dalam melakukan kegiatan perusahaan dengan pelanggan".

Masalah yang sudah dinyatakan mengharuskan untuk melakukan komunikasi dengan pelanggannya selama masa Pandemi Covid-19 dan memberlakukan bekerja dari rumah (work form home) serta bekerja dari kantor (WFO) dengan cara bergantian dalam satu minggu kerja, dengan membaginya dengan system kerja bagi staff bekerja di kantor (WFO) dua kali dalam satu minggu, sedangkan untuk bagian manajemen kehadiran di kantor (WFO) disesuaikan dengan kebutuhan saja.

Dalam berkoimunikasi selama masa pandemic COVID-19 dilakukan dengan cara memanfaatkan kemajuan dari teknologi yaitu penggunaan video konfrensi sebagai media yang dapat menggantikan tatap muka dengan para pelanggannya. Dikarenakan banyaknya permintaan, complain dari para pelanggan dan juga berkenaan dengan kebijakan yang diambil oleh perusahaan menyebabkan pihak perusahaan melakukan upaya dalam menghadapi pandemic COVID-19. Semua masalah harus dilakukan komunikasi serta didiskusikan antara pihak perusahaan dan juga pelanggannya. Maka Perusahaan melakukan komunikasi dan hubungan dengan pelanggan penggunaan sebuah media untuk melakukan komunikasi dengan Zoom Cloud Meeting sebatai pertemuan secara online.

Pada pelaksanaan komunikasi dengan cara online atau daring mengalami berbagai kendala, dan hal inilah yang dialami oleh PT Mandiri Cipta Sejahtera saat berkomunikasi dengan pelanggan, serta dalam pengambilan keputusan. Bila melihat kondisi yang dialami perusahaan tersebut dan melakukan strategi customer relations dengan menggunakan video konfrensi, maka menjadikan ketertarikan bagi peneliti untuk melaksanakan sebuah penelitian tentang strategi customer relations yang dilakukan oleh PT Mandiri Cipta Sejahtera di dalam kondisi pandemic COVID - serta strategi customer relations 
didalam penggunaan Zoom Cloud Meeting yang termasuk kedalam bagian dari kekayaan media.

Sebagai langkah untuk menjawab masalah diatas, maka yang digunakan oleh peneliti yaitu teori Computer Mediated Communications theories yang dicetuskan oleh Wood dan Smith, dimana model dari komunikasi yang dilakukan pada saat majunya teknologi dengan menggunakan internet serta membuat pergerakan dengan cepat atau tertuju komunikasi dengan penggunaan computer sebagai medianya. (Wood dan Smith, 2014)

Salah satu bagian dari teori Computer Mediated Communication atau CMC adalah teori kekayaan media atau yang biasa disebut dengan Media Richness yang diungkapkan oleh Richard Daft dan Robert Lengel yaitu "The media extravagance of a verbal trade time is chosen by (1) its data transfer capacity or cappotential to send more than one prompts, (2) its cappotential to give on the spot criticism, (3) its cappotential to help utilizing natural or conversational language, and (4) its nonpublic concentration". (Kekayaan media dari suatu teknologi komunikasi ditetapkan pada; (1) mampu menyampaikan berbagai tanda (2) mampu menyampaikan jawaban dengan cara langsung (3) mampu dalam mendukung dalam pemakaian bahasa secara umum, (4) focus pada dirinya sendiri bukan konsentrasi pada public (Thurlow, Lengel, dan Tomic, 2004)

Sebagai acuan dari pendapat diatas, maka rumusan masalah pokok dalam penelitian ini yaitu : 1) Bagaimana Strategi Customer Relations dari PT Mandiri Cipta Sejahtera dalam kondisi pandemic COVID-19? 2) Bagaimana penggunaan dari video conference Zoom Cloud Meeting sebagai kekayaan media dalam strategi customer relations PT Mandiri Cipta Sejahtera dalam kondisi pandemic COVID19 ?

Sedangkan penelitian ini bertujuan: (1) Mencari tahu dan melakukan analisa strategi custommer relations PT Mandiri Cipta Sejahtera dalam kondisi Pandemi COVID-19; (2) Mencari tahu dan melakukan analisa penggunaan dari video conference Zoom Cloud Meeting sebagai Kekayaan Media dalam strategi customer relations PT. Mandiri Cipta Sejahtera dalam kondisi pandemic COVID-19.

Paradigma yang digunakan dalam penelitian ini adalah Postpositivist. Menurut Popper dalam (Ronda, 2018) "Postpositivisme yaitu sebuiah paradigma dari suatu pengetahuan dan memiliki pemikiran mengenai realitas betul dan terbukti dan juga nyata sepertihalnya sebuah hukuk alam. Meskipun seseorang tidalkah wajib untuk selalu memperoleh susatu hal yang benar adanya apabila selalu mempunyai jarak dan terlibat dengan apa yang menjadi kenyataan. Membuat seseorang untuk melaksanakan sebuah telaah guna melakukan interaksi."
Sebagai acuan pustaka, penlis menggunakan acuan pustaka sebagai perbandingan akan uniknya dan juga otentiknya penelitian ini.adalah sebagai berikut:(1) penelitian yang dilakukan oleh Windra Irawan (2015), dengan mengangkat sebuah penelitian mengenai kekayaan media dengan penerimaan pengguna serta kehadiran social bersama dalam video conference dengan hasil diperolehnya adalah terdapat kaitan yang didapat yaitu moderate dengan kontribusi dapat signifikan diberuikan dua variabel independen itu. Sekalipun bisa disimpulkan semankin tinggi kehadiran bersama sosial pada kegiatan komunikasi dengan menggunakan media video conference. Bila melihat penelitian tersebut mempunyai kesamaan pada penelitian yang dilakukan oleh peneliti, yaitu berpijak pada Teori Kekayaan Media, hanya saja dalam penelitian ini menggunakan penerimaan pengguna (user acceptance) terhadap teknologi dan kehadiran bersama sosial (social copresence) sedangkan pada penelitian yang dilakukan oleh penulis terfokus pada penggunaan video conference yang merupakan media kaya dalam Teori Kekayaan Media. (2) Kemudian pada penilitian yang dilakukan oleh Risma Dian Atika (Atika dan Nurjanah, 2014), yaitu meneliti mengenai strategi customer relations dalam meningkatkan kepuasan pelanggan dimana penelitiannya pada Hotel Dyan Graha Pekanbaru, dengan hasil yang di dapat adalah strategi yang dilakukan pada perusahaan itu guna peningkatan pada kepuasan dari pelanggan yaitu dengan melakukan sebuah kegiatan family gathering, program social tanggung jawab dan program promosi. Selanjutnya penulis menemukan beberapa factor. Kesamaan dengan penelitian ini adalah menngunakan konsep Strategi Customer Relations, sedangkan perbedaan dengan penelitian ini adalah terletak pada penggunaan teori, dimana pada penelitian yang dilakukan oleh Atika adalah teori Komunikasi Two Ways Symetrical oleh Grunig sedangkan pada penelitian ini peneliti menggunakan berbeda dengan penelitian ini, peneliti menggunakan konsep strategi customer relations menurut Cutlip.

Pendapat Morissan (2010) mengenai Customer relations yaitu "semua yang dilakukan perusahaan untuk menjaga hubungan antara perusahaan dengan konsumennya sebagai pelanggan yang loyal. Customer relations memiliki focus pada dua bidang, yaitu melaksanakan tatakelola hubungan dengan konsumen yang sudah dipunyai sebelumnya (customer retentions) juga melaksanakan kegiayan untuk mencari konsumen yang baru atau calon pelanggan (customer acquisition).

Terciptanya peningkatan dan kepercayaan yang diperoleh dari para konsumennya pada sebuah perusahaan, maka untuk melakukan tatakelola dari Sstrategi customer relations bisa dijalankan pada beberapa langkah, seperti yang dinyatakan oleh Cutilp dalam (Atika dan Nurjanah, 2014) yaitu; (1) Fact-finding, pada langkah ini untuk melakukan 
pencarian dari kenyataan yang ada ataupun faktanya mengenai keadaan dan pendapat masyarakat mengenai langkah yang dilaksanakan oleh perusahaan, yaitu kejadian apa saja yang menjadi penyebab terhambatnya suatu penunjang dalam pelaksanaan kegiatan perusahaan; (2) Planning and programming, susudah didaptkan permasalahan yang terjadi dari fakta yang ada pada langkah pertama (fact-finding),maka pada tahapan berikutnya adalah melakukan sebuah rancangan atau rencana dalam beberapa tahapan secara rinci dan berjesinambungan, (3) Taking action and communicating, sedangkan pada langkah ini adalah pelaksanaan dari program yang telah dibuat dan direncanakan sebelumnya, juga melakukan komunikasi bertujuan meraih pada apa yang sudah diputuskan, Pada tahapan yang dilaksanakan ini bisa membuat jelas dari sebuah informasi mengenai apa saja yang wajib dilakukan, dan pada akhirnya akan timbul sebuah kesan sesuatu yang sangat diperlukan serta memiliki potensi sebagai dukungan secara penuh pada perusahaan. (4) Evaluasi, pada tlangkah ini merupakan sebuah kegiatan dari usahanya untuk menilai sebuah program atau kegiatan. Sehingga dapat mengetahui apa saja yang diperlukan dan keinginan serta harapan dari para pelanggan bisa terpenuhi dan diperlukannya pengukuran dengan cara bermacam-macam metode. Kegiatan yang dilakukan seorang Public Relation Officer dalam melakukan kegiatan customer relations menurut Ruslan (2010), adalah: (1) melakukan sebuah layanan unggul (service oriented) yang terdiri dari: pelayanan prima (service off excellence)serta menangani berbagai keluhan, (2) menjalankan suatu hubungan yang baik dengan para konsumennya (good relationship) yang terdiri dari menyiarkan informasi juga memberikan prestasi ataupun tanda penghargaan atas keberhasilan yang diraih pelanggannya.

Pelayaan prima atau service of excellence itu sendiri menurut Ruslan (2010) adalah: Suatu tindakan atau cara yang dilakukan dalam customer service (pelayanan pelanggan) bisa melakukan sebuah pelayanan yang baik terhadap pelanggan dengan mencari kepuasan. Dalam konsep yang terdapat di dalam pelayanan prima ini mempunyai beberapa unsur yang utama, yaitu: (1) Kecekatan (cepat), (2) Tepat, (3) Ramah, (4)Nyaman.Dari empat bagian tersebut menjadi satu kesatuan dalam sebuah layanan yang lekat di bidang jasa, maksudnya adalah terdapat pada sebuah layanan jasa tersebut yang ditujukan kepada pelanggan, dan tidak akan menjadi excellence atau unggul bila salah satu diantaranya tidak tercapai.

Service excellence atau pelayanan prima yaitu bagian terpenting yang wajib untuk dilakukan oleh banyaknya perusahaan agar selalu bertahan didalam dunia persaingan pada era saat ini. Sedangkan menurut Saleh dalam (Kadari, 2016) "Pelayanan prima (service excellence) merupakan suatu apa saja yang dilakukan perusahaan untuk memberikan apa yang dibutuhkan dan diharapkan oleh pihak customer dengan cara yang sesuai dengan keingingan mereka".

Teori Computer Mediated Communications (CMC) yang diungkapkan oleh Andrew F. Wood dan Matthew J. Smith (2014), yaitu; In this segment, we begin to find PC interceded dispatch (CMC) as a mix of PC time with our customary lives. The subject of CMC research how human practices are kept up with or adjusted with the guide of utilizing change of information through machines". (dengan kemajuan dalam teknologi informasi pada saat ini, sebagai model sebuah hubungan komunikasi pada umumnya dipakai dengan terhubung pada sebuagh jaringan internet, juga dapat berkembang dengan sangat cepat hingga pemaiakain Computer Mediated Communications (CMC) terlihat pada koalisi teknologi komputer dalam kehidupan manusia sehari-hari).

Pemakaian komputer merupakan media yang digunakan menyamoaikan pesan dari satu orang pada oranglainnya dan apabila dilakukan perbandingan dengan media tatap muka (yang telah melakukan pengiriman dan pemaknaan dari sebuah symbol dengan memakai tubuh dan juga pemikiran, sehingga dengan adanya media teknologi informasi yang dilakukan interprestasi, pengartian, atau diwujudkan dalam sebuah makna. Kata-kata, gerak gerik tubuh dan lain-lainnya secara umum dapay dipakai untuk komunikasi secara tatap muka, sedangkan didalam media teknologi yang terdiri dai email, percakapan, hubungan video atau sebuah system yang mempunyai basis virtual reality lainnya.

Teori komunikasi didalamnya memuat sebuah teori yang dijasikan sebuah dasar dan juga patokan didalam menggunakansuatu media di sebuah perusahaan, dan juga bisa digunakan sebagai pijakan akademik tentang strategi dalam menggunakan media komunikasi pada sebuah perusahaan.

Perkenalan akan tori Kekayaan Media oleh Richard L.Daft dan Robert H. Lengel (1986) yang merupakan perkembangan teori Pengolahan Informasi (Information Processing Theory). Pertamakali dicetuskannya teori ini pada permasalahan mengenai komunikasi yang dilakukan dalam sebuah organisasi, dan tidak pada komunikasi yang ditujukan pada massa. Penelitian pertama yang mereka lakukan terjadi ketidak samaan dalam pemahaman juga pertentangan untuk keputusan dalam lingkup organisasi sehingga efeknya dalam menggunakan saluran dalam melakukan komunikasi belum tepat. Contohnya dalam pembicaraan mengenai sesuatu hal yang darurat dan peka dimana seharusnya dilakukan pembicaraan dengan cara tertutup atau empat mata, atau di dalam menggunakan sebuah surat ataupun email yang membahas mengenai kritikan maka bisa berakibat salah ataupun kegagalan untuk memahaminya, maka 
sebetulnya bisa saja dengan menggunakan saluran telepon.

Richard Daft dan Robert Lengel yaitu "The media extravagance of a verbal trade time is chosen by (1) its data transfer capacity or cappotential to send more than one prompts, (2) its cappotential to give on the spot criticism, (3) its cappotential to help utilizing natural or conversational language, and (4) its non-public concentration". (Kekayaan media dari suatu teknologi komunikasi ditetapkan pada; (1) mampu menyampaikan berbagai tanda (2) mampu menyampaikan jawaban dengan cara langsung (3) mampu dalam mendukung dalam pemakaian bahasa secara umum, (4) focus pada dirinya sendiri bukan konsentrasi pada public (Thurlow, Lengel, dan Tomic, 2004)

Teori kekayaan media yang diungkapkan Daft dan Lengel, penjabarannya sebagai berikut: 1) Kemampuan dari sebuah media untuk pengungkapan bahasa isyarat yang bermacam-macam (multiple cues) seperti intonasi, kerasnya suara, gerakan tangan, dan juga symbol dari raut wajah lainnya.2) pengungkapan umpan balik dengan segera (feedback immediacy), yaitu kemampuan dalam kecepatan dari media didalam menerima respon dari pesan yang diterimanya, 3) penggunaan bermacam bahasa (language variety) yaitu kata-kata, angka, perhitungan dengan menggunakan rumus, symbol dan juga lambang yang lainnya, 4) kemampuan yang dilakukan oleh media tersebut untuk focus seseorang dalam melakukan komunikasi dengan cara langsung kepada penerima pesan atau juga kemampuan media dalam menjadikan pesan yang memiliki sebuah sifat langsung sesuai denga apa yang diterima lawan bicaranya. (Venus dan Munggaran, 2017)

\section{METODOLOGI PENELITIAN}

Pendekatan kualitatif dengan penggunaan metode deskriptif merupakan metode yang dilakukan pada penelitian ini. Penelitian yang berupa kualitatif berdasarkan pendapat dari Kirk dan Miller dalam (Moleong, 2013)didefinisikan penelitian kualitatif merupakan proses eksklusif pada ilmu dari ranah social dengan cara mendasar dan tergantung pada hasil dari susatu yang telah diamati seseorang di wilayahnya dan adanya hubungan dengan orangorang tersebut.

Pada pengumpuln data yang digunakan pada penelitian ioni adalah menggunakan metode observasi dengan cara tidak langsug dikarenakan pada saat penelitian ini dilakukan, kondisi masih dalam masa pandemic COVID-19, dan pencarian datanya menggunakan media internet, serta melakukan wawancara kepada 2 orang key informan, Agung (Senior Manager Marketing PT Mandiri Cipta Sejahtera) dan Siti (Supervisor Eksternal PT Mandiri Cipta Sejahtera) serta informan dari pelanggan, Hasan Sumarji (Supervisor PT Unilever Indonesia), serta penulis mencari data pada halaman website perusahaan yaitu pada website
PT Mandiri Cipta Sejahtera www.morena.co.id, serta beberapa media sosial perusahaan.

Sedangkan dalam teknik Analisis data yang digunakan oleh peneliti adalah menganalisis data dari Huberman dan Miles merupakan reduksi data yang dilakukan dengan menggunakan cara pengumpulan dari data yang diperoleh dari hasil jawaban dari beberapa pretanyaan yang dilakukan peneliti dengan key informan dan informan, juga rekaman dari pelaksanaan pertemuan online yuang dilakukan perusahaan menggunakan Zoom serta berkas atau informasi yang diperoleh dari wevbsite resmi perusahaan, dan juga beberapa akun media social dari MorenaRent.

\section{HASIL DAN PEMBAHASAN}

1. Strategi Customer Relations yang dilakukan oleh PT Mandiri Cipta Sejahtera dalam kondisi pandemic COVID-19

\section{a. Fact-finding (Pengumpulan beberapa permasalahan yang ada sesuai dengan fakta):}

Peraturan pemerintah tersebut menjadi permasalahan yang besar bagi PT Mandiri Cipta Sejahtera yang harus mentaati akan peraturan tersebut, yaitu dengan menetapkan kebijakan bagi karyawannya untuk tidak sepenuhnya bekerja dari rumah (WFH), yaitu dengan menerapkan pembagian kerja bekerja dari rumah (work form home) serta bekerja dari kantor (WFO) dengan cara bergantian dalam satu minggu kerja, dengan membaginya dengan system kerja bagi staff bekerja di kantor (WFO) dua kali dalam satu minggu, sedangkan untuk bagian manajemen kehadiran di kantor (WFO) disesuaikan dengan kebutuhan saja.

Permasalahan yang timbul tidak hanya bidang prosedural yang mengalami permasalahan, tetapi dalam kegiatan berkomunikasi antara perusahaan dengan pelanggan pun mengalami permasalahan, bahkan sampai terjadinya banyak pelanggan yang melakukan putus kontrak dikarenakan kendala dalam proses pembayaran penagihan mengalami kesulitan dalam komunikasi dengan pihak perusahaan. Sehingga dapat menyebabkan kemunduran dalam pendapatan dan juga roda khidupan perusahaan, diperkuat dengan pernyataan Agung;

"Banyak masalah timbul itu karena masalah komunikasi, yang akhirnya pelanggan putus kontrak hanya karena komunikasi, seperti misalnya permasalahan / kendala pembayaran atau mengganti invoice saja, pihak pelanggan mengalami kesulitan dalam menghubungi marketing". (Nugroho, 2021)

Bila melihat dari beberapa pendapat di atas, maka permasalahan yang terjadi dikarenakan 
hubungan komunikasi, permasalahan yang dihadapi oleh perusahaan selama masa pandemic Covid-19 ini diantaranya adalah kesulitan dalam berkomunikasi antara perusahaan dengan pelanggan, dan juga pendekatan perusahaan dengan pelanggan dari berbagai lini perusahaan, dari staff hingga jajaran direksinya sangat sulit untuk dihubungi, salah satu contohnya adalah dalam tagihan atau invoice yang seringnya mengalami keterlambatan karena pemberlakuan bekerja dari rumah (Work Form Home atau WFH). maka dapat menyebabkan mundurnya kemajuan dalam berbagai bidang di dalam perusahaan hingga terjadinya beberapa pelanggan yang melakukan putus kontrak sewa kendaraan sebelum waktunya habis dikarenakan komunikasi dengan pelanggan yaitu berkenaan dengan kesulitannya melakukan komunikasi seperti kendala pembayaran atau mengganti invoice, dan besar penurunan jumlah pelanggan yang dialami perusahaan selama pandemic sekitarr $20 \%$ dari jumlah pelanggan yang bermitra dengan perusahaan, yaitu jumlah pelanggan sebelum adanya pandemic terdapat sekitar 58 pelanggan, maka sejak adanya pandemic turun menjasi sekitar 47 pelanggan. Kondisi seperti ini mengharuskan perusahaan mencari upaya untuk memudahkan komunikasi dengan pelanggan, yaitu dengan memanfaatkan teknologi komunikasi atau komunikasi dengan menggunakan komputer sebagai medianya.

b. Planning and programming

Perencanaan atau planning dapat dikatakan sebagai bagian yang teramat penting dikarenakan dalam tahapan ini perusahaan akan membuat sebuah perencanaan yang dapat memecahkan permasalahan yang terjadi, khususnya dalam komunikasi dengan pelanggan. Pada tahapan ini juga akan mempertimbangkan langkah yang tepat untuk dijadikan sebagai program sebagai kebijakan dari perusahaan.

Berdasarkan hasil jawaban dari beberapa pertanyaan yang diajukan peneliti pada kedua key informan kedua key informan dari PT Mandiri Cipta Sejahtera bahwa dengan adanya pembatasan dan perubahan untuk mengharuskan mereka bekerja dari rumah membuat kesulitan dalam hal berhubungan atau berkomunikasi dengan para pelanggannya, maka perusahaan mencari upaya dan langkah yang dapat menghadapi permasalahan yang dihadapi perusahaan khususnya untuk membina hubungan baik dengan para pelanggannya.
"Program "Visit and call" merupakan cara yang dibuat oleh perusahaan untuk menciptakan perhatian pelanggan tidak berjalan pada masa pandemic, yang dapat dilakukan perusahaan adalah "call", yaitu dengan menghubungi customer dengan menggunakan WhatsApp, Zoom dan media lainnya ke $P I C$ masing-masing pelanggan dan terjadwal seminggu sekali”.(Nugroho, 2021)

PT Mandiri Cipta Sejahtera dalam menghadapi masa pandemic yang menyebabkan kesulitan dalam menghubungi pelanggannya khususnya dengan melakukan "visit" atau mendatangi perusahaan dari pelanggan mereka, maka langkah yang harus mereka lakukan adalah mengupayakan untuk melakukan "calls” dengan cara lebih banyak atau melaksanakan komunikasi dengan para pelanggan mereka dan juga melakukan pengurangan pada "visit"atau kegiatan mengunjungi perusahaan dari pelanggan mereka. Selain penggunaan penggunaan Zoom Cloud Meeting dan WhatsApp dalam strategi customer relations sebagai tahapan kedua adalah penggunaan melakukan pengukuran kepuasan pelanggan dengan memberikan kuesioner sebagai feedback dari pelanggan atas kekurangan ataupun kebebihan pelayanan yang telah dilakukan oleh perusahaan, yaitu sengan menggunakan Customer Service Index (CSI). Perusahaan juga membuat sebuah cara yang dapat memudahkan pelanggan mereka untuk dapat menghubungi perusahaan atau PIC dari perusahaan sebagai langkah untuk mempersingkat tersalurkannya keluhan pelanggan secara langung dalam waktu 24 jam dan dapat terkoneksi pada email, website, email customer service, serta Whatsapp khusus VOC PT Mandiri Cipta Sejahtera, program ini disebut Voice of Customer (VOC).

\section{c. Taking Action and Communicating}

Pada tahap ini perusahaan melakukan kegiatan komunikasi dengan pelanggan sebagai langkah untuk membina hubungan jangka panjang yang tercipta dengan para pelangganntya.

Perusahaan melaksanakan berbagai kegiatan secara teratur dan terjadwal untuk lebih mengutamakan kegiatan "calls" setidaknya dalam seminggu sekali melakukan komunikasi dengan pelanggan untuk mengontrol perkembangan dari pelanggannnya menggunakan media komunikasi dengan WhatsApp serta konfrensi video (video conference) yaitu penggunaan Zoom Cloud Meeting dalam menyelesaikan 
permasalahan dengan cara lebih detail dan mendalam,

Pada tahap taking action and communicating yang dilakukan PT Mandiri Cipta Sejahtera melaksanakan kegiatan berkomunikasi dengan pelanggannya dalam kondisi pandemic COVID-19 dengan selalu mengutamakan kegiatan "calls" yaitu dengan menggunakan media yang terhubung dengan internet seperti WhatsApp untuk permasalahan yang masih dapat dipecahkan dengan menggunakan telephone WhatsApp sesuai dengan jadwal yang telah ditentukan yaitu satu minggu sekali, atau dengan menggunakan media komputer dan juga jaringan internet untuk melakukan pertemuan virtual atau konfrensi video (video conference) menggunakan Zoom Cloud Meeting untuk menyelesaikan, mendiskusikan dan membicarakan permasalahan yang membutuhkan penangan lebih mendalam.

d. Evaluasi

Tahap evaluasi yang dilakukan oleh perusahaan atas suatu kegiatan yang telah dilakukan adalah dengan menggunakan standar dari kepuasan yang dirasakan oleh pelanggan-nya, maka PT Mandiri Cipta Sejahtera hasil dari kepuasan pelanggan berdasarkan kuesioner sebagai feedback dari perusahaan terhadap pelayanan yang telah dilakukan perusahaan, yaitu menggunakan Customer Service Index (CSI), kemudian perusahaan akan melakukan pembenahan apabila terdapat kekurangan, Seperti yang dijelaskan oleh Agung;

"Kita biasanya sebelum adanya pandemic selalu menggunakan CSI sebulan sekali, CSI (Customer Service Index) yaitu mengukur kepuasan pelanggan dengan memberikan kuesioner sebagai feedback dari mereka akan kekurangan dan kelebihan dari perusahaan ".(Nugroho, 2021)

Sedangkan untuk kepuasan pelanggan dalam penggunaan media dalam melakukan komunikasi antara perusahaan dengan pelanggannya, yaitu dengan penggunaan Zoom Cloud Meeting, Agung pun mengatakan bahwa pelanggan benar merasakan puas karena dapat bernegoisasi dengan menggunakan media sangat berbeda dengan pertemuan tatap muka, dimana dalam bernegoisasi menggunakan melakukan pertemuan virtual menggunakan konfrensi video (video conference) yaitu penggunaan media Zoom Cloud Meeting dapat dilakukan dengan cara menarik ulur dan terkadang beberapa dari pelanggan merasakan kurang puas dengan melakukan pertemuan dengan menggunakan Zoom yang harus dilakukan hingga berkali-kali bahkan bila dirasa masih belum juga dapat terselesaikan, pelanggan meminta untuk melakukan pertemuan tatap muka

2. Kegiatan Customer Relations yang dilakukan PT Mandiri Cipta Sejahtera

Perusahaan melakukan kegiatan customer relations yang dilakukan, yaitu berupa kegiatan perusaaan dalam upayanya membina hubungan baik dengan pelanggan, yaitu;

a. Melaksanakan pelayanan yang unggul (Service Oriented), yang terdiri dari :

1) Pelayanan prima (service off excellence) Program pelayanan prima yang dilakukan PT Mandiri Cipta Sejahtera dalam membina hubungan baik dengan pelanggan adalah selalu mengedepankan dan mengutamakan kebutuhan pelanggan serta menerima dan merespon setiap keluhan dari pelanggan.

Hal ini dapat terlihat dari pernyataan kedua key informan akan komunikasi yang baik di dalam menghadapi berbagai permasalahan dengan pelanggan PT Mandiri Cipta Sejahtera, sebagai berikut;

"Empat karakter yang harus dan wajib untuk setiap marketing adalah bersikap ramah dengan pelanggan, itu harus dapat humble, komunikatif, atraktif dan harus dapat membangun suasana". (Nugroho, 2021)

Sebagai langkah untuk menjalin hubungan yang baik dengan pelanggannya, PT Mandiri Cipta Sejahtera telah melakukan empat unsur pokok sesuai dengan konsep service of excellence, yaitu:

a) Perusahaan berusaha untuk melakukan kecepatan dalam menangani keluhan dari pelanggan, membuat sebuah sarana komunikasi langsung dari pelanggan ke pihak perusahaan sebagai saluran berbagai keluhan dan complain, yaitu Voice Of Customer (VOC).

b) Kemudian pada unsur pokok berikutnya adalah ketepatan di dalam menangani dan mengambil langkah untuk menyelesaikan masalah, seperti yang telah dilakukan oleh perusahaan di dalam menangani permasalahan yang terjadi khususnya pada masa pandemic dengan mengedepankan program "calls", Sebagai media dalam kegiatan komunikasi itu adalah dengan menggunakan WhatsApp, dan juga Zoom Cloud Meeting.

c) Komunikasi yang dilakukan antara perusahaan dengan pelanggannya selalu menggunakan etika dan bahasa yang 
ramah, sesuai dengan syarat dasar yang dimiliki marketing pada PT Mandiri Cipta Sejahtera, salah satunya adalah dapat melakukan komunikasi dengan baik dan selalu menjaga sikap yang penuh dengan etika dan keramahan. Kemudian untuk sikap perusahaan terhadap pelanggan, Sumarji juga mengungkapkan sebagai berikut;

"MorenaRent dapat kooperatif dalam setiap memecahkan permasalahan, juga para marketingnya ramah dalam memberikan pelayanannya kepada kami sebagai pelanggannya, tidak jarang mereka menelpon hanya untuk menanyakan kondisi kami dan perusahaan kami selama masa pandemic ini”. (Sumarji, 2021)

d) Ketiga unsur pokok yang telah disebutkan sebelumnya, apabila dilakukan maka akan menimbulkan suatu kenyamanan dan juga kepuasan dari pihak pelanggan untuk bermitra dengan perusahaan, seperti yang diungkapkan oleh Sumarji sebagai berikut;

"Selama pandemic ini MorenaRent selalu memberikan pelayanan yang baik, sehingga kami merasakan nyaman untuk bermitra dengan Morena”. (Sumarji, 2021)

Penanganan keluhan pada perusahaan ini dilakukan dengan menggunakan Voice of Customer (VOC) sebagai media yang dapat menghubungkan anatara pelanggan dan perusahaan hingga ke lini teratas dalam perusahaan agar dapat ditangani dengan segera, dan apabila penanganan membutuhkan pembicaraan yang detail, maka dibutuhkan pertemuan dengan menggunakan Zoom Cloud Meeting. Keluhan pelanggan pada masa pandemic lebih banyak mengenai keterlambatan masalah pembayaran atau tagihan (invoice), sebelum pandemic permasalahan tagihan dapat terselesaikan dalam tiga hari, tetapi sejak adanya pandemic mengalami keterlambatan sampai berningguminggu. Semua permasalahan ini dapat teratasi dengan melakukan pendekatan dan komunikasi langsung dengan pihak pelanggan dan kemudian perusahaan akan memberikan solusi yang tidak memberatkan pelanggan tetapi juga tidak merugikan pihak perusahaan.

\section{PEMBAHASAN}

PT Mandiri Cipta Sejahtera melakukan kegiatan strategi customer relations yaitu dengan penggunaan video konfrensi pada aplikasi Zoom Cloud Meeting. Dapat terlihat pada apa yang telah dijelaskan sebelumnya alasan digunakan Zoom dikarenakan aplikasi Zoom memiliki kelengkapan dalam sarananya, salah satunya adalah dapat melakukan penyesuaian berkas atau data serta dapat melakukan negoisasi dengan cara ditampilkannya berkas penting dalam kegiatan negoisasi tersebut.

\section{a. Media mampu menyampaikan berbagai} tanda:

Hasildari analisa peneliti berdasarkan rekaman pelaksanaan pertemuan online perusahaan dengan salah satu pelanggannya menggunakan Zoom bisa memperkuat dalam analisa peneliti sebelumnya dimana perusahaan beranggapan bahwa dalam pelaksanaan pertemuan menggunakan Zoom Cloud Meeting tidak dapat dilakukan sepenuhnya untuk mengirimkan banyaknya isyarat dikarenakan camera video peserta tidak diaktifkan sehingga kondisi seperti ini tidak mungkin dilakukan. Hal ini terlihat pula pada video pelaksanaan pertemuan dengan menggunakan Zoom dimana peserta tidak mengaktifkan camera web selama pelaksanaan pertemuan, termasuk pada saat pemaparan presentasi yang dilakukan oleh pelanggan dan juga lekakukan sharing file dan juga dilakukan minimize dalam ruang pertemuan Zoom hal ini dimaksudkan untuk lebih terfokus pada presentasinya daripada memperhatikan wajah pesertanya.

b. Pengungkapan umpan balik dengan segera (feedback immediacy):

Rapat ataupun pertemuan yang dilakukan menggunakan cara online dengan Zoom menjadikan komunikasi yang terjadi secara timbal balik antara perusahaan dengan pelanggannya dapat dilakukan menjadi lebih mudah dekalipun dalam jarak yang berjauhan. Komunikasi yang dilakukan dengan menggunakan media online seperti halnya komunikasi tatap muka hanya saja dalam komunikasi online bergantung pada signal atau koneksi dan jaringan internet yang harus dalam kondisi stabil, seperti yang dinayatkan oleh Agung Setio Nugroho sebagai berikut;

"Selain itu respon terhambat juga berkenaan dengan beberapa informasi yang membutuhkan respon dari customer, tetapi yang dilakukan justru pihak customer melakukan sesuatu hal yang tidak transparant, yaitu mereka melakukan chatt dengan perserta lainnya dari pihak mereka untuk melakukan mute dan kemudian mereka berdiskusi menggunakan telepon, dan akhirnya memutuskan untuk melakukan stop untuk meeting". (Nugroho, 2021)

c. Mampu dalam mendukung dalam pemakaian bahasa secara umum, 
Agung menyatakan bahwa seringkali di dalam pelaksanaan pertemuan atau rapat perusahaan dengan pelanggannya dengan menggunakan Zoom selalu menggunakan sharing file atau data.

d. focus pada dirinya sendiri bukan konsentrasi pada public

Sedangkan pada pertemuan online yang biasa dilakukan oleh perusahaan dengan menggunakan Zoom dapat dilakukan dengan cara lebih terpusat perhatian pada apa yang sedang di presentasikan dan tidak terganggu dengan selaan atau perkataan dari pihak manapun.

\section{KESIMPULAN}

1. Strategi Customer Relations yang dilakukan oleh PT Mandiri Cipta Sejahtera dalam kondisi pandemic COVID-19, pada langkah pertama yaitu Fact Finding atau pengungkapan permasalahan yang terjadi sesuai dengan faktanya terlihat adanya permasalahan akibat terjadinya pandemic COVID-19 yaitu melakukan suatu keputusan untuk mengikuti aturan pemerintah untuk melakukan pekerjaan kantor di rumah masing-masing (WFH), sehingga perusahaan harus dapat menggunakan perkembangan teknologi dalam informasi dan komunikasi dengan menggunakan komputer sebagai media yang tepat untuk menjalankan hubungan yang baik dengan para pelanggannya; kemudian untuk tahapan kedua yaitu Planning and programming, dimana perusahaan membuat sebuah cara yang dapat menghubungkan antara perusahaan dengan pelanggan yaitu berupa program Customer Service Index (CSI) yang dijadikan sebagai alat ukur dari kepuasan para pelanggannya. Selain itu dibuat pula program VOC dimana para pelanggan mereka dapat dengan mudah, cepat dan langsung dapat berhubungan dengan PIC dari perusahaan,yaitu dengan menggunakan WhatsApp, sambungan komunikasi menggunakan telepon serta konfrensi video (video conference) dengan aplikasi Zoom Cloud Meeting khusus untuk membahas berbagai permasalahan yang detail dan mendalam; kemudian untuk langkah ketiga yaitu Taking action and communicating, perusahaan lebih mengutamakan penggunaan komunikasi atau "calls", seperti penggunaan komunikasi dengan sambungan telepon melalui aplikasi WhatsApp serta penggunaan pertemuan online yaitu berupa konfrensi video (video conference) dengan aplikasi Zoom Cloud Meeting untuk memecahkan permasalahan yang memerlukan diskusi mendalam dan detail; Dan yang tahapan terakhir adalah evaluation, perusahaan mendapat nilai yang baik oleh CSI dalam kepuasan pelanggan, kemudian permasalahan yang masuk dalam program VOC dapat terselesaikan dengan baik oleh perusahaan, serta dalam komunikasi lebih banyak penggunaan komunikasi menggunakan WhatsApp dan juga Zoom Cloud Meeting. Sedangkan untuk pelaksanaan dari kegiatan Customer Relations, seperti service oriented yang terdiri dari; layanan yangh prima dengan dilakukan secara cepat untuk memberikan respon dari berbagai complain dan juga keluhan dari para pelanggannya, juga perusahaan dapat dengan tepat memberikan solusi dari permasalahan dengan pelanggannnya.

2. Di dalam pelaksanaan pertemuan secara online dengan menggunakan konfrensi video (video conference) dengan aplikasi Zoom Cloud Meeting yang dilakukan perusahaan sebagai strategi Customer relations, yaitu penggunaan teori kekayaan media Kekayaan media sebagai salah satu dari teori Computer Mediated Communications (CMC) dengan ditentukan oleh oleh (1) Media mampu menyampaikan berbagai tanda, (2) Pengungkapan umpan balik dengan segera (feedback immediacy), (3) Mampu dalam mendukung dalam pemakaian bahasa secara umum dan yang terkahir (4) focus pada dirinya sendiri bukan konsentrasi pada public. Maka dari keempat kemampuan ini, hanya satu yang tidak terpenuhi yaitu Media Zoom Cloud Meeting belum dapat dinyatakan mampu mengirimkan banyak isyarat. Zoom sebetulnya merupakan sebuah media yang tergolong media miskin dari teori kekayaan media, apabila dalam melakukan pertemuan dengan menggunakan media sepertihalnya ZOOM tidak dapat dilakukan dalam satu pertemuan saja, tetapi bisa dilakukan lebih dari satu pertemuan, dan juga peserta lebih banyak yang tidak menampilkan video camera, dan hingga pada akhirnya komunikasi yang dirasakan dan dibutuhkan adalah komunikasi tatap muka yang merupakan sebagai media terkaya. Akan tetapi terlepas dari permasalahan yang terjadi, penggunaan Zoom Meeting merupakan pilihan media yang terbaik sebagai strategi customer relations pada saat pandemic dan pemberlakuan system kerja dari rumah (WFH)

Kendala yang terjadi pada saat dilakukan pertemuan menggunakan Zoom Meeting, maka peneliti menyarankan (1) agar menetapkan jadwal dengan tepat serta menggunakan fitur record guna merekam pertemuan tersebut dengan tujuan untuk dapat dijadikan sebagai langkah untuk mengevaluasi dari pertemuan sebelumnya dan tidak mengharuskan mengulang beberapa kali pertemuan. Penggunaan camera web pada saat pertemuan virtual zoom meeting dalam kondisi aktif untuk semua peserta rapat, serta menggunakan virtual background yang sudah disesuaikan dengan tema dalam pertemuan tersebut, sehingga semua peserta dapat lebih fokus untuk mengikuti pertemuan tersebut dan dapat 
memecahkan permasalahan dengan baik. Seperti layaknya pertemuan tatap muka, maka pada pertemuan zoom meeting diharapkan untuk dapat diikuti oleh semua peserta hingga pertemuan berakhir sebagai komitmen perusahaan maupun pelanggan untuk memecahkan permasalahan bersama-sama. (2) Selain itu penelitian ini diharapkan diharapkan hasil dari dapat menambah khasanah dan literature ilmiah khususnya dalam penelitian yang berkaitan tentang strategi customer relations yang dilakukan oleh sebuah perusahaan pada masa pandemic COVID-19 khususnya dalam penggunaan konfrensi video Zoom Cloud Meeting.

\section{REFERENSI}

Atika, R. D., \& Nurjanah. (2014). STRATEGI CUSTOMER RELATIONS DALAM MENINGKATKAN KEPUASAN PELANGGAN PADA HOTEL DYAN GRAHA PEKANBARU. Jurnal Online Mahasiswa (JOM) Bidang Ilmu Sosial Dan Ilmu Politik Universitas Riau, 1(1). Retrieved from

https://jom.unri.ac.id/index.php/JOMFSIP/arti cle/view/2106

Irawan, W. (2015). User Acceptance dan Media Richness pada Video conference dalam Kehadiran Bersama secara Sosial (Social Copresence). JURNAL Komunikasi Indones, IV(1). Retrieved from http://journal.ui.ac.id/index.php/jkmi/article/vi ew/8875/pdf

Kadari. (2016). Pelayanan Prima (Service Excellence) pada Pelanggan. Jurnal Prima Ekonomika, 7(1). Retrieved from http://jurnal.stieykp.ac.id/index.php/primaekonomika/article/view/11

Moleong, L. J. (2013). Metodologi Penelitian Kualitatif (31st ed.). Bandung: PT. Remaja Rosdakarya.

Morisan. (2010). Manajemen Public Relations: Strategi Menjadi Humas Profesional. Jakarta: Prenada Media Group.

Mungkasa, O. (2020). Bekerja dari Rumah (Working
From Home/WFH): Menuju Tatanan Baru Era Pandemi COVID 19. The Indonesian Journal of Development Planning, IV(2), 126-150. Retrieved from https://journal.bappenas.go.id/index.php/jpp/ar ticle/download/119/81/

Nugroho, Aguing Setio. Wawancara di awal. , (2020).

Nugroho, Agung S. Transkrip Wawancara Key Informan 1. , (2021).

Ronda, A. M. (2018). Tafsir KonteporerIlmu Komuniksi (I). Tangerang: Indigo Media.

Ruslan, R. (2010). Manajemen Public Relations dan Media Komunikasi. Jakarta: PT Raja Grafindo Persada.

Sumarji, H. Hasil wawancara customer PT Mandiri Cipta Sejahtera. , (2021).

Thurlow, C., Lengel, L., \& Tomic, A. (2004). Computer Mediated Communication - Social Interaction And The Internet (1st ed.). London: SAGE Publications Ltd.

Venus, A., \& Munggaran, N. (2017). MENELUSURI PERKEMBANGAN TEORI KEKAYAAN MEDIA. DIALEKTIKA, 4(1), 299. Retrieved from http://journal.unla.ac.id/index.php/dialektika/a rticle/view/299

Wood, A., \& Smith, M. (2014). Online Communication (2nd ed.). Retrieved from http://commres.net/wiki/_media/online_comm unication_linking_technology_identity_and_c ult_2005.pdf

\section{PROFIL PENULIS}

Susilowati, S. Sos, MM sebagai dosen di Universitas Bina Sarana Informatika Jakarta

Dr. Titi Widaningsih M.Si sebagai dosen di Pascasasarjana Universitas Sahid Jakarta

Dr.Toto Subandoro M.M sebagai dosen di Pascasarjana Universitas Sahid Jakarta 